\title{
MEMBER PARTICIPATION IN THE WTO DISPUTE SETTLEMENT SYSTEM: CAN DEVELOPING COUNTRIES AFFORD NOT TO PARTICIPATE?
}

\author{
Navneet Sandhu*
}

\begin{abstract}
Reflections on the progress of the WTO over the last two decades highlights low developing country participation in its dispute settlement system as a fundamental failing of the multinational trading system. Recurrently, this low participation rate has been attributed to the cost of the WTO's legalistic model in Panel and Appellate Body proceedings, creating a concern of bias. Yet, by focussing on the inherent costs of the system, critics ignore the real ways in which developing countries can and have used the WTO dispute settlement system to offset the costs. Therefore, this article argues that developing countries are more disadvantaged in their lack of internal capacity to identify and progress legitimate violations to the WTO. Only by addressing the capacity issue can an accurate cost and benefit analysis of the WTO dispute settlement system take place.
\end{abstract}

\section{A. INTRODUCTION}

The World Trade Organization's (WTO) dispute settlement system celebrates its 20th anniversary this year as 'the central pillar of the multilateral trading system'. ${ }^{1}$ One of the main areas of reform with which the dispute settlement system came into existence was: 'Recognizing further that there is need for positive efforts designed to ensure that developing countries and especially the least developed among them, secure a share in the growth in international trade commensurate with the needs of their economic development.' ${ }^{2}$ Although much has been debated of its early success and failures, the two decades since its implementation has seen the changes in patterns of trade and global growth remain largely unreflected in the use of the dispute settlement system by developing countries. Despite this, recent calls for reform of the system have been quiet and the seemingly everlasting Doha Round reveals a complacency and lack of political will at the top. This paper hopes to recapture the original debate on the position of developing countries within the dispute settlement system and, at a minimum, show that notwithstanding the current complacency of its members the dispute settlement system does have much cause to celebrate.

It is argued here that the dispute settlement system has been successful in sustaining a rule of law that has been proven to benefit developing countries. The 'legalistic' approach of

\footnotetext{
* Navneet Sandhu LLB, LLM.

${ }^{1}$ World Trade Organization, 'Understanding the WTO: Settling Disputes'

<thewto_e/whatis_e/tif_e/disp1_e.htm> accessed 8 June 2015.

${ }_{2}$ Marrakesh Agreement Establishing the World Trade Organization 15 April 1994, 1867 UNTS 154; 33 ILM 1144 (1994), Preamble.
} 
the dispute settlement system provides developing countries with an independent recourse to remedies for inconsistent trade barriers. Although often stated to have come at the expense of developing countries' ability to participate in the system, it is argued here that the success of the dispute settlement system should not be diminished by the inherent costs. Developing countries must acknowledge that they risk greater long term damage to trade terms by not participating in the dispute settlement system, compared with the initial costs of participation. The importance of the dispute settlement system lies in the fact that this is where members 'play for the rules', shaping interpretation of trade agreements. ${ }^{3}$ Therefore developing countries cannot afford to remain outside of the process. The trends in developing country participation show that those countries that use the WTO dispute settlement system have done so in ways that successfully offset some of its costs (through their use as a third party, consultations and ACWL.) The fact that smaller countries habitually do not participate shows that the problem is not in the framework of the dispute settlement system, but with developing members identifying when it is worth using it. As a self-representative system, developing countries must be willing to invest and make use of the options that the WTO does provide. As lack of participation is largely a problem of capacity rather than cost, reform must come mainly from within developing members with a focus on awareness and government engagement with the private sector. This paper suggests ways in which this reform can take place.

\section{B. THE IMPORTANCE OF DEVELOPING COUNTRY PARTICIPATION IN THE WTO DISPUTE SETTLEMENT SYSTEM}

The purpose of the WTO dispute settlement system is to solve trade disputes between WTO members to ensure the smooth flow of trade based on WTO principles. ${ }^{4}$ Thus the WTO dispute settlement system relies on active engagement by all members in order to create a judicial system which ultimately provides 'a level playing field' for litigants based on the rule of law. In order to promote participation by all members, it is important to make members aware of its benefits. Shaffer accurately highlights three primary reasons why active participation is imperative. Firstly, 'the specific economic outcome of WTO disputes ${ }^{5}$ makes engagement with WTO proceedings important. As the most apparent reason for the initiation of WTO proceedings these specific outcomes are likely to be part of a cost-benefit analysis driving

\footnotetext{
${ }^{3}$ Gregory Shaffer and Ricardo Melendiz-Ortiz (eds), 'Dispute settlement at the WTO: The Developing Country Experience' (CUP 2013), Preface.

${ }^{4}$ The World Trade Organization <https://www.wto.org/> accessed 22 August 2015.

${ }^{5}$ Shaffer and Melendiz-Ortiz (n 3), Preface.
} 


\section{Member Participation in the WTO Dispute Settlement Process: Can Developing Countries Afford Not to Participate?}

members' decision-making. On the whole, countries can calculate in monetary terms the prospective gains of lifted trade barriers and therefore the prospective benefits of filing WTO proceedings. Following from this is that 'failure to participate in the WTO dispute settlement system can have term of trade effects that adversely affect the overall social welfare of the country ${ }^{6}$ Although these may be harder to calculate than the specific economic outcomes, term of trade effects in relation to a country's market access and trade relationships must also be taken into consideration when weighing the cost of initiating WTO proceedings.

More importantly, often overlooked by WTO members is the effect that each dispute has on interpretation and application of WTO jurisprudence. ${ }^{7}$ Beyond the specific stakes of WTO disputes are the long-term consequences that participation has on future bargaining positions. ${ }^{8}$ Through participation with the system, countries are able to voice their opinions on specific aspects of WTO law, contributing to the shaping and interpretation of WTO agreements. When countries systematically fail to participate in the dispute settlement system, as most developing countries have, they risk losing this platform to further individual trade aims within the WTO. The essential point is that members taking part in the dispute settlement system are not solely arguing for or against specific interpretations of WTO law, but are also 'playing for the rules': how the law should be interpreted and with what purpose. In this respect, WTO disputes shape the future bargaining position of members by deciding which trade interests must be protected. ${ }^{9}$ This idea is all the more important as the WTO dispute settlement system is still relatively new and thus malleable to the purpose with which its agreements are interpreted. As a form of international law the WTO agreements themselves are 'still largely soft law agreements, with ambiguities and gaps in their provisions'. ${ }^{10}$ In clarifying these ambiguities and filling in the legal gaps there is considerable space for members to influence the future direction of trade law. It is for this reason that participation by both developed and developing countries is vital.

Moreover, Mosoti and others propose that participation in the WTO dispute settlement system is not only of value to members for progression of their individual aims, but can be considered a 'public good'. ${ }^{11}$ All members benefit from increased participation in the system

\footnotetext{
6 ibid.

7 ibid.

8 ibid.

9 ibid.

${ }^{10}$ Dennis Browne, 'Dispute Settlement in the WTO: How Friendly is it for the LDCs' (2005) 45 CPD Occasional Paper <http://www.cpd.org.bd/pub_attach/OP45.pdf> accessed 20th July 2015, 37.

11 Victor Mosoti, 'Africa in the First Decade of WTO Dispute Settlement' (2006) 9(2) J Intl Econ L 427, 432.
} 
as the 'litigation creates greater clarity of WTO rules'. ${ }^{12}$ Bown and Hoekman also subscribe to this idea as they consider that the dispute settlement system 'improves property rights - in this context market access rights'. ${ }^{13}$ Participation in the dispute settlement system therefore adds certainty to otherwise unclear trade agreements. With greater certainty follows more investment and international transactions to the benefit of all trading nations. ${ }^{14}$ At the same time, the ability of the dispute settlement system to act as a 'public good' should not be confused with the reality that the dispute settlement system requires a strong element of selfrepresentation. All members have equal opportunity to use the system in furthering their interpretation of trade agreements in so far as they are willing and able to articulate their own interests.

This paper goes on to show that all members are able to use the system so long as governments are willing to invest in doing so. As individuals, private companies or NGOs have no standing to bring violations to the WTO: only governments are able to initiate proceedings. Bown has been among the supporters of the view that self-representation can create a bias against developing countries. The basis of a self-representation system relies on the concept that 'countries have sufficient resources to both monitor and recognize relevant WTO violations and to fund legal proceedings in cases in which their rights have been violated' ${ }^{15}$ Yet as evidence shows, not all developing countries can afford to do so. The increased legalistic nature of the dispute settlement system has resulted in a high cost of WTO litigation that developed countries are able to absorb more easily then developing countries, which places developed countries in an advantageous position. The result of this can be seen in the disparities in participation rates among developed and developing countries. Hence it is suggested that the WTO dispute settlement system is institutionally biased, ${ }^{16}$ pricing developing countries out of their ability to participate within the system.

However, such criticism of the WTO dispute settlement system misunderstands the conceptual foundations on which it works. The self-representation element of the dispute settlement system is not biased against developing countries, but instead builds a legitimate

\footnotetext{
12 ibid.

${ }^{13}$ Chad P Bown and Bernard M Hoekman, 'WTO dispute settlement and the missing developing country cases engaging the private sector’ (2005) 8(4) J Intl Econ L 861, 862.

14 ibid.

${ }^{15}$ Chad P Bown, 'Participation in WTO dispute settlement - complainants, interested parties and free riders' (2005) 19(2) The World Bank Economic Review 287, 287.

${ }^{16}$ Henrik Horn, Petros C Mavroidis, and Hakan Nordström, 'Is the Use of the WTO Dispute Settlement System Biased?' (2009) CEPR discussion paper 2340

<www.cepr.org/active/publications/discussion_papers/dp.php?dpno=2340> accessed 18 July 2015, 2354.
} 


\section{Member Participation in the WTO Dispute Settlement Process: Can Developing Countries Afford Not to Participate?}

judicial system based on the rule of law. The Panel and Appellate Body process within the WTO dispute settlement system focusses on an adversarial model requiring proactive initiation of proceedings and direct engagement. As will be discussed further in this paper, despite perceived access issues this litigation model creates 'a level playing field' for complainants and respondents, as the court of law gives parties equal bargaining positions from which to state their legal arguments. In this manner the WTO dispute settlement system encompasses the notion of 'right before might'. ${ }^{17}$ Developing countries therefore have most to gain from such a judicial system where the strength of legal argument rather than leverage is the determining factor for Panel and Appellate Body decisions. Related to this is the inevitability of costs in order to maintain the legitimacy of the system. In any case, as in all judicial systems limitation in time and resources within the WTO dispute settlement system means that the system would risk being over burdened by cases if there were no cost of participation. Consequently the inherent costs make the system viable: '[i]f there were no implicit "user fees", the dispute settlement system would implode. It has to cost something to keep out nuisance cases of insignificant value'. ${ }^{18}$ Hence developing countries must recognise that although the dispute settlement system is costly, these costs must be borne in order to ensure its legitimacy.

Furthermore, the requirement of self-representation and self-initiation of WTO dispute settlement proceedings is in keeping with the fact that the WTO is not a supranational entity but a judicial one. In order for the dispute settlement system to maintain its legitimacy as a member-driven organisation, governments must be the driving force in WTO litigation. A selfrepresentation framework in the dispute settlement system therefore ensures that it is members who determine the direction of WTO law as it is members that bring complaints. Moreover, the self-initiation of proceedings under the WTO means that governments maintain accountability within their countries. When governments are accountable, they must justify to industry and exporters their decision to bring or not bring claims to the WTO. The benefit of this approach is that it drives more proactive decision-making by member governments forcing them to weigh up the costs and benefits in each case. As will be discussed further in a later section, this also motivates members to debate important trade policy issues within their governments and build greater trade capacity. Consequently this paper argues that in weighing up the costs and benefits of participating within the WTO dispute settlement system, developing countries need to give due weight to the wider strategic importance of active

\footnotetext{
${ }^{17}$ Shaffer and Melendiz-Ortiz (n 3) Preface.

${ }^{18}$ Hakan Nordström and Gregory Shaffer, 'Access to justice in the World Trade Organization: a case for a small claims procedure?’ (2008) 7(4) World Trade Review 587, 587.
} 
participation, and as it will go on to argue, embrace the means within the WTO dispute settlement system to offset inherent costs.

\section{THE PROBLEM OF LOW PARTICIPATION BY DEVELOPING COUNTRIES}

Participation in the dispute settlement system is defined broadly evaluating the trends with which the members access and use the system. This discussion therefore looks at the initiation of Panel and Appellate Body proceedings by members, as well as how members use the dispute system beyond litigation to further their trade interests. In doing so, this paper does not overlook developing countries' participation in other aspects of the WTO, including trade negotiation rounds where they can be seen to play a more active role. ${ }^{19}$ Instead, the paper focusses on participation in the dispute settlement system for the practical importance that WTO jurisprudence plays in the interpretations and implementation of world trade law.

The continued accession of new countries into the WTO, the Seychelles being the latest to join in April 2015, ${ }^{20}$ suggests that WTO membership remains strategically important for countries in managing global trade relations. Yet, despite its extensive membership of 161 countries, the majority of WTO members have had minimal participation in the dispute settlement system. In particular, the stark difference in participation levels between developed and developing countries has been a long recurring criticism of the dispute settlement system. Since its establishment in 1995, the EU and US have dominated dispute settlement proceedings as respondents or complainants in 80 percent of WTO cases. ${ }^{21}$ In contrast, developing countries have accounted for only 46 percent of all cases. ${ }^{22}$ Yet even within these figures, trends show that only a select few developing countries have participated in WTO disputes on more than one occasion. Brazil, Mexico, India and Argentina lead developing country participation in the dispute settlement system. ${ }^{23}$ Abbot argues that as a result the data creates a 'false picture' ${ }^{24}$ of developing country participation, as the figure is dominated by these select WTO members

\footnotetext{
${ }^{19}$ Gustav Brink, 'South Africa's Experience with International Trade Dispute Settlement' in Shaffer and Melendiz-Ortiz (n 3) 253.

20 The World Trade Organization, 'Accessions' < https://www.wto.org/english/thewto_e/acc_e/acc_e.htm> accessed 19 July 2015.

${ }^{21}$ Kara Leitner and Simon Lester, 'WTO Dispute Settlement 1995-2014-A Statistical Analysis' (2015) 18(1) J Intl Econ L 203, 205.

22 ibid.

${ }^{23}$ Shaffer and Melendiz-Ortiz (n 3) 2.

${ }^{24}$ Roderick Abbott, 'Are Developing Countries Deterred from Using the WTO Dispute Settlement System? Participation of Developing Countries in the DSM in the years 1995-2005' Ecipe Working Paper No. 01/2007 $<$ http://www.ecipe.org/app/uploads/2014/12/are-developing-countries-deterred-from-using-the-wto-disputesettlement-system.pdf $>$ accessed 10 August 2015, 6 .
} 


\section{Member Participation in the WTO Dispute Settlement Process: \\ Can Developing Countries Afford Not to Participate?}

who 'are among the most advanced and most active in international trade'. ${ }^{25}$ A classic illustration of this is Argentina which, in 2006, had been a respondent or complainant in 12 percent of all cases despite its contribution of world trade accounting for only 0.3 percent. ${ }^{26}$ Hence, while large developing countries are over-represented in the system, smaller developing countries remain disengaged.

The problem of a lack of developing country participation is therefore more acute when looking at the patterns of participation in smaller developing countries. Whilst there is a general habit in the literature on the WTO to group all developing countries into the same category, the WTO does distinguish in its agreements those least developed countries (LDCs). LDCs, following a UN definition based on low-income, human asset index, and economic vulnerability, are those that have the lowest social economic development. ${ }^{27}$ Although 34 of the 48 LDCs are members of the WTO, ${ }^{28}$ LDC participation in the WTO dispute settlement system is virtually non-existent. With the exception of Bangladesh as the only LDC to have brought a compliant to the Panel, ${ }^{29}$ the data shows LDCs to be disconnected with the dispute settlement system as a whole. The issue is exacerbated as there is also a geographical divide in participation rates. This supports the notion of inherent issues in the accessibility of the WTO dispute settlement system. Since 1995, few African countries have initiated Panel proceedings. 'With the exception of South Africa and Egypt, which have the most experience with the functioning of the process, the rest of the delegations are only tangentially interested in the issue. ${ }^{30}$ This raises concern about the lack of diversity in the dispute settlement system.

Notwithstanding the problem in labelling countries as 'developing', this paper continues to use the term broadly in order to evaluate the participation of the group as a whole and identify trends in the way they use the system. Constraints on the information available on the internal factors driving small developing country participation in WTO dispute settlement system makes a full bottom-up assessment ${ }^{31}$ difficult. However, from the data available on developing country participation, certain assumptions and comparisons can be made to identify trends in the group's use of the system. In doing so, developing countries can be differentiated

\footnotetext{
25 ibid.

${ }^{26}$ José L Pérez Gabilondo, 'Argentina's Experience with WTO Dispute Settlement: Development of National Capacity and The Use of In-House Lawyers', in Shaffer and Melendiz-Ortiz (n 3) 105.

27 The United Nations, 'LDC Criteria' <http://www.un.org/en/development/desa/policy/cdp/ldc/ldc criteria.shtml > accessed 21 July 2015

28 World Trade Organization, 'LDCs' < https://www.wto.org/english/thewto_e/whatis_e/tif_e/org7_e.htm> accessed 28 July 2015.

${ }^{29}$ India - Anti-Dumping Measures on Batteries from Bangladesh WT/DS306/3.

${ }^{30}$ Mosoti (n 11) 442.

${ }^{31}$ Shaffer and Melendiz-Ortiz (n 3) preface.
} 
through their use of the system enabling the identification of some of the individual problems facing countries.

\section{REASONS FOR LOW PARTICIPATION WITHIN DEVELOPING COUNTRIES: A COST AND CAPACITY DEBATE}

In this paper explanations for low participation among developing countries are broadly distinguished into cost and capacity issues. ${ }^{32}$ Here, cost issues describe the price of using the dispute settlement system which can usually be calculated by members in monetary terms. These costs are factored into the overall cost-benefit analysis members perform when deciding whether to initiate WTO proceedings. In contrast, capacity issues refer largely to internal issues within countries that jeopardise the member's ability to participate fully in the system; they are often individual to each member country. Although the two issues are largely interlinked, the distinction between the two helps to pinpoint where the problem of low participation lies and methods of possible reform. It is true that there are inherent costs in the WTO dispute settlement system, yet these are, on balance, successfully offset by provisions within the same system. The trends in developing country participation show that the problem principally lies in members' ability to identify viable legal cases to bring to the WTO. The real problem is not cost, but one of capacity.

\section{Issues of cost}

As touched on above, cost issues associated with the dispute settlement system are of predominant concern to developing countries when attempting to participate in the WTO. The increased legalistic nature of the dispute settlement system from its predecessor, the General Agreement on Tariffs and Trade (GATT), has been central to the high-cost of WTO litigation. The approach under the old GATT system worked on the basis of a "small "club" of likeminded trade policy officials working together'. ${ }^{33}$ The 1994 Marrakesh Agreement introduced a Dispute Settlement Body and an Appellate Body, resulting in a new judicial system for international trade disputes. ${ }^{34}$ The changes strengthened the legal basis of dispute proceedings and created a more structured litigation model than had previously existed. An inherent consequence of the more legalistic system has become the increased cost of using the WTO dispute settlement system. Due to the greater technical aspects of law that has followed from

\footnotetext{
${ }^{32}$ Browne (n 10).

${ }^{33}$ Robert E Hudec, 'The New WTO Dispute Settlement Procedure: An Overview of the First Three Years' (1999) 8 Minn J Global Trade 1, 5.

${ }^{34}$ Marrakesh Agreement Establishing the World Trade Organization 15 April 1994, 1867 UNTS 154; 33 ILM 1144 (1994).
} 


\section{Member Participation in the WTO Dispute Settlement Process: Can Developing Countries Afford Not to Participate?}

the litigation model, a certain level of expertise is now required in order for countries to participate in proceedings. The cost of hiring experts and trade lawyers in order to manoeuvre within the legal structure has resulted in the increased overall cost of participation.

Similarly, the substantial number of WTO cases each year, contributing to the rising total of 497 cases, ${ }^{35}$ has made understanding and digesting the legal intricacies of WTO law costly for members. The reality of the situation is that 'the jurisprudence of the WTO grows with each passing year, making it necessary to read numerous book-length Panel and Appellate Body decisions in order to properly understand the legal context.' ${ }^{36}$ Taking into consideration both the cost of lawyers and increased effort in discerning legal arguments from lengthy WTO decisions, the cost of WTO litigation has been estimated at $\$ 500,000 .{ }^{37}$ The further risk is that 'with uncertainty, if exporters consistently over-estimated the litigation costs and/or underestimated the increase in profits associated with market access benefits, this would also increase the likelihood that an exporter would choose not to initiate a dispute at the WTO.' ${ }^{38}$ Bown and Hoekman submit that the suggested figure is likely to be at the lower end of estimates as it includes neither 'the resources necessary to investigate potential claims in the pre-litigation phase, nor the resources necessary to engage public relations and/or political lobbying in the post-litigation phase to generate compliance. ${ }^{39}$ Hence the knowledge that WTO litigation is extremely costly, alongside difficulties in measuring with certainty the exact cost, can lead to developing countries choosing not to initiate proceedings even in situations where they have a legitimate case.

Moreover, the resulting disruption to a country's trade during WTO disputes shows additional costs associated with initiation of dispute settlement proceedings. There is little comment in the literature as to what happens to trade figures within litigating countries during disputes. Nonetheless a logical assumption can be made that trade between the two litigating countries will be adversely affected by the ongoing dispute. As follows, lengthy WTO disputes can cause wider damage to the economy of the countries involved. As cases in the WTO can take up to two years, ${ }^{40}$ the effect felt is long-lasting. Any further delays in the process can therefore weaken the bargaining powers of complainants. Certain structural provisions within

\footnotetext{
${ }^{35}$ World Trade Organization (n 4).

${ }^{36}$ Andrew Guzman and Beth A Simmons, 'Power plays \& capacity constraints - the selection of defendants in WTO disputes.' (2005) 34(2) JLS 557, 567.

${ }^{37}$ Mosoti (n 11) 429.

${ }^{38}$ Bown and Hoekman (n 13) 868.

39 ibid 870.

${ }^{40}$ Mosoti (n 11) 430.
} 
the dispute settlement system, such as selection of Panel members and a mandatory consultation process prior to initiation of Panel proceedings, can facilitate a respondent's ability to delay at the expense of complainants. ${ }^{41}$ As developed countries absorb these costs more easily then developing countries, developing countries may feel greater pressure to settle disputes on unfavourable terms in an attempt to limit loss in trade.

The problem is exacerbated by the absence of compensation for loss of trade. As compensation is not applied retrospectively within the WTO, violating members do not have to pay for the loss of trade caused by their breach of WTO articles prior to Panel and Appellate Body decisions. In this way lengthy WTO litigation creates additional costs to trade with the knowledge that compensation for breaches is unlikely. One proposal for reform is for developing countries to receive compensation for the duration of the violating measure. ${ }^{42}$ This, however, has the ability to add to the uncertain costs of WTO litigation for members, causing respondents to be in a worse bargaining position. Browne goes on to suggest that 'such compensation should also be paid if the developed country unilaterally withdraws the measure before completion of proceedings' ${ }^{43}$ Yet if this were the case, it would be likely that developed countries would be further motivated to litigate to the end and less willing to settle at an early stage. This would be to the cost of developing countries. Alternatively, 'a Panel might ask the respondent to suspend the measure in dispute for a specified period' ${ }^{44}$ This is a better method to avoid the loss of trade during WTO disputes as it means that attempts to delay proceedings will not impede a developing country's bargaining position.

More radical reform has been suggested to the legal framework of the WTO dispute settlement system in order to reduce its cost to developing countries. China has proposed reform to the WTO dispute settlement proceedings by shifting the burden of cost to developed countries. In cases where the Appellate Body rules in favour of a developing country it is suggested that the developed country should pay for the developing country's legal costs, thus reducing the developing country's cost of participation. ${ }^{45}$ Despite mitigating the litigation costs for developing countries, such an approach would be imbalanced. As discussed above, the costs of WTO dispute settlement system are inherent costs that must be borne by all members to

\footnotetext{
${ }^{41}$ Pornchai Danvivathana, 'Thailand's Experience in the WTO Dispute Settlement System: Challenging the EC Sugar Regime' in Shaffer and Melendiz-Ortiz (n 3) 224.

${ }^{42}$ Browne (n 10) 28.

43 ibid.

44 ibid 25.

${ }^{45}$ Magda Shahin, 'WTO Dispute Settlement for a Middle-Income Developing Country: The Situation in Egypt' in Shaffer and Melendiz-Ortiz (n 3) 280.
} 


\section{Member Participation in the WTO Dispute Settlement Process: \\ Can Developing Countries Afford Not to Participate?}

ensure equality under the law. As developing countries benefit from using the system, it is not surprising that they must also bear some of its costs.

Mention should also be made of the proposal that the WTO should put in place a small claims procedure. ${ }^{46}$ Nordström and Shaffer's principal argument for this is that the WTO dispute settlement system in its current form 'is not neutral to size'. ${ }^{47}$ Small developing countries and LDCs are constrained in their ability to use the dispute settlement system as their low volume of world trade means that the increased market access they would achieve through successful litigation would be little relative to the costs. ${ }^{48}$ In addition to the rudimentary issues such as defining 'small' claims, ${ }^{49}$ to have such a separate system alongside the WTO dispute settlement system would worsen the problem that such a procedure wishes to address. The idea that the WTO dispute settlement system currently lacks legitimacy due to the fact that developing members are failing to participate will be exacerbated if small developing countries instead use a small claims procedure. ${ }^{50}$ The principal criticism is 'that a remedy of monetary compensation could create an incentive for developed countries to buy themselves out of their WTO obligations through the payment of compensation, rather than complying with them, thereby undoing agreed trade concessions' ${ }^{51}$ The proposal is therefore based on the assumption that financial concerns are the decisive factor for developing countries. However, as previously noted, specific financial outcome is not the only reason for participation in the dispute settlement system: of equal importance are the wider issues of terms of trade and bargaining positions. Consequent to the adoption of a small claims procedure, the WTO dispute settlement system would become 'a rich man's tool of economic subjugation'. ${ }^{2}$ As small developing countries would avoid using the dispute settlement system, they would no longer be part of the process of shaping of trade law or 'playing for the rules'. Thus, money spent creating a small claims procedure would be better used for making improvements to the single WTO dispute settlement system.

Bown and Hoekman identify two different approaches that can be taken when attempting to reform the cost of the WTO dispute settlement system. Whilst '[o]ne is to reduce the cost of litigation through systemic reform[,] [t]he other is to take the system as given and

\footnotetext{
${ }^{46}$ Nordström and Shaffer (n 18) 587.

47 ibid 588.

48 ibid.

49 ibid 597.

50 ibid 592.

${ }^{51}$ Gosego Rockfall Lekgowe, 'The WTO Dispute Settlement System: Does it Work for Developing Countries?' (2012) <http://ssrn.com/abstract=2045470> accessed 8 July 2015, 19.

52 ibid 3.
} 
investigate how litigation costs could be lowered for poor countries.' ${ }^{53}$ Like Bown and Hoekman, it is argued here that the latter of these approaches is most effective. Integral within WTO law is the principle of preferential treatment towards developing countries. The WTO dispute settlement system recognises the problems that developing countries and LDCs face in engaging with the legal framework. The WTO Agreement contains within it 'special and differential treatment provisions' which aim to protect the economic interests of developing countries as they must be taken into consideration in applying the substantive law. Arguably of more importance here is the 'special and differential treatment' bestowed on developing countries procedurally. The Dispute Settlement Understanding (DSU) contains articles providing developing countries and LDCs with special treatment from the consultation stage to the implementation stage. Article 12(10) for example states that '.. in examining a complaint against a developing country Member, the panel shall accord sufficient time for the developing country Member to prepare and present its argumentation. ${ }^{54}$ Likewise Article 8(10) allows developing countries to request at least one panellist from a developing country. These provisions support the interests of developing countries by granting them greater time to prepare legal cases. As we have seen, developing countries are burdened by the increased efforts in discerning legal cases. In this way additional time to prepare should mitigate the associated costs.

In principle the WTO therefore facilitates developing country needs in the dispute settlement system. Nevertheless, in reality these provisions may not be practical. As mentioned above, the loss of trade during lengthy disputes adversely affects developing countries; time delays could therefore worsen this situation. The WTO dispute settlement system had attempted to address the issue of delays with its 1966 Decision, ${ }^{55}$ which allows for accelerated consultation and panel procedures when a developing country member brings a complaint against a developed country Member. ${ }^{56}$ Lekgowe argues, however, that its provisions are 'a gust of wind without substance and benefits for developing countries'. ${ }^{57}$ The fact that the accelerated procedure has not been applied suggested that developing countries do prefer more time. ${ }^{58}$

\footnotetext{
${ }^{53}$ Bown and Hoekman (n 13) 864.

${ }^{54}$ Dispute Settlement Rules: Understanding on Rules and Procedures Governing the Settlement of Disputes (DSU) (1994).

${ }^{55}$ Decision of 5 April 1966 on procedures under Article XXIII.

56 World Trade Organization, 'Decision of 5 April 1966 on procedures under Article XXIII' $<$ https://www.wto.org/english/tratop_e/dispu_e/disp_settlement_cbt_e/a2s1p1_e.htm> accessed 20 August 2015. ${ }^{57}$ Lekgowe (n 51) 5.

58 ibid.
} 


\section{Member Participation in the WTO Dispute Settlement Process: Can Developing Countries Afford Not to Participate?}

Despite the cumbersome cost of litigation, developing countries have methods available to them to offset this within the WTO. The most successful of these has been the ACWL. Although independent from the WTO, the ACWL works as part of the wider support network available to developing country members to reduce costs. The organisation takes a two -tier approach to support; providing legal services at reduced fees for developing countries and providing sufficient training on WTO law, the latter of which will be discussed later in this paper. Even though the ACWL is jointly funded by its 11 developed and 32 developing country members, it is the developed countries that provide most of the funding to the ACWL Endowment Fund and Working Capital Fund. ${ }^{59}$ The ACWL follows WTO principles in providing LDCs with preferential treatment as LDCs do not need to contribute to the budget and are not required to become members of the ACWL before being able to use its services. ${ }^{60}$ The ACWL also provides free legal advice on procedural and substantive issues of WTO law for all members up to a certain number of hours. ${ }^{61}$ Developing countries are banded into three categories based on their world trade and per capital income (LDCs constituting a fourth band). These bands reflect the hourly rate charged for ACWL support in WTO proceedings applying levels of discount progressively. ${ }^{62}$ The extent of the ACWL's benefits is shown by the fact that legal fees are likely to be discounted by as much as 90 percent for LDCs. ${ }^{63}$

As well as providing its own legal services at a reduced fee, the ACWL creates a network of private international law firms who also agree to provide external counsel for a reduced price. ${ }^{64}$ By doing so, the ACWL provides expert legal advice to developing countries at a fraction of the cost of private law firms. As legal fees are a large proportion of the overall costs of WTO litigation, 'the ACWL lowers the overall costs of the self-enforcement process' ${ }^{65}$ The consequence of this on developing country participation is that 'the ACWL allows countries to file more sole-complainant disputes on behalf of their exporters' ${ }^{66}$ and therefore to be proactive. This is demonstrated by the fact that in the 43 WTO cases in which

\footnotetext{
59 Advisory Centre on WTO Law, 'Members' < http://www.acwl.ch/e/members/developed_countries.html> accessed 18 August 2015.

60 ibid.

${ }^{61}$ Advisory Centre on WTO Law, 'Annex IV: Schedule Of Fees For Services Rendered By The Centre' $<$ http://www.acwl.ch/e/documents/Annex_IV.pdf> accessed 18 August 2015.

62 ibid.

63 ibid.

64 ibid.

${ }^{65}$ Chad P Bown and Rachel McCulloch, 'Developing countries, dispute settlement, and the Advisory Centre on WTO Law’ (2010) 19(1) The Journal of International Trade \& Economic Development 33, 55.

66 ibid 36.
} 
the ACWL has provided assistance to developing countries, those countries have acted in their capacity as complaints rather than respondent or third parties. ${ }^{67}$

Yet, the ACWL is not without its limits. Although it provides legal advice on WTO law and support in WTO proceedings, this is dependent on requests for help by developing countries. ${ }^{68}$ The ACWL also does not provide developing countries with support at the investigatory stage: "the ACWL has neither the resources nor the mandate to go out into the field and provide information to developing country exporters that they have a legally viable case that they could pursue at the WTO to enforce their market access rights. ${ }^{99}$ This issue reflects the core concern with developing countries' lack of participation in the WTO dispute settlement system, namely governments' inability to decide when to bring cases to the WTO. Since the ACWL does not have economists to provide technical economic consulting services, ${ }^{70}$ this means that "without economic expertise and insight, it can provide no information on the size of the economic benefit to pursuing a case.' ${ }^{71}$ This has resulted in the same pattern of participation forming in the ACWL that there has been in the WTO dispute settlement system. The same few developing countries are taking advantage of the ACWL while the majority of developing countries and LDCs remain detached. To date, Thailand accounts for 20 percent of the ACWL's cases and Columbia 12 percent. ${ }^{72}$ Subsequently, developing countries new to WTO proceedings may lose the chance of ACWL support as the centre is only able to support one developing country in cases where two developing countries desire its assistance. In this way the ACWL misses its aim of introducing new countries to the WTO dispute settlement system. ${ }^{73}$

Furthermore, Bown and McCulloch argue that having the ACWL worsens the problem of identifying cases to bring to the WTO, 'to the extent that they discourage private law firms from ambulance chasing - ie generating information on behalf of prospective developingcountry clients'. ${ }^{74}$ Possible reform of the system may therefore lie in the ACWL creating greater ties with international private law firms. Working jointly on cases with private law firms generates the evidence and expertise needed within countries to identify violations in

\footnotetext{
67 ibid 48.

${ }^{68}$ Bown and Hoekman (n 13) 874.

69 ibid.

70 ibid 876.

71 ibid.

72 Advisory Centre on WTO Law, 'Assistance in WTO dispute settlement proceedings since July 2001' <http://www.acwl.ch/e/disputes/WTO_disputes.html>accessed 12 August 2015.

73 Bown and McCulloch (n 65) 33.

74 ibid 60 .
} 


\section{Member Participation in the WTO Dispute Settlement Process: Can Developing Countries Afford Not to Participate?}

return for a greater number of prospective developing country clients. A greater number of international firms offering pro-bono services would also raise competition and lower overall prices. A redirection of funding towards monitoring trade violations in developing countries would be beyond the ACWL's mandate and would result in a loss of essential legal support for developing countries. Moreover, funding developing countries directly through the ACWL or WTO in order to allow developing countries and LDCs to initiate proceedings would be of less value then keeping the money centrally. Splitting the money between numerous developing countries means that funds would not go as far. An expansion of funding to the ACWL to do so may also be practically difficult as 'a rich country government may be hesitant to sufficiently fund a legal assistance centre that ultimately provides litigation assistance directly challenging its own actions. ${ }^{75}$ Furthermore, this would create dependence by developing countries on the ACWL funding, which cannot be seen as a long term solution.

Alternatively, a more strategic use of the WTO dispute settlement system by developing countries can mean that they avoid the high costs of litigation whilst gaining the experience needed. As discussed above, participation in the dispute settlement system is not confined to members' ability to initiate Panel and Appellate Body proceedings. Although Panel and Appellate Body proceedings are central to the dispute settlement system, alternative means of settlement also exist. Article 25(1) of the DSU states that 'Expeditious arbitration within the WTO as an alternative means of dispute settlement can facilitate the solution of certain disputes that concern issues that are clearly defined by both parties. ${ }^{76}$ Members also have alternative dispute resolution methods available to them in the form of good offices, conciliation or mediation, which 'may be requested at any time by any party to a dispute'. ${ }^{77}$ In this way, members benefit from the fact that they can bring violations to the WTO framework beyond litigation. A focus on a diplomatic means of resolution through these provisions means that developing countries will not have to bear the high costs associated with litigation. The cost of lawyers and a lengthy process are bypassed through direct negotiations. This gives developing countries flexibility in how they participate in the dispute settlement system to resolve trade violations.

Nonetheless, what it is more telling about developing countries' attitudes towards the WTO dispute settlement system is the fact that these alternative dispute resolution methods are

\footnotetext{
75 Bown and Hoekman (n 13) 874.

${ }^{76}$ Art 25(1) DSU.

${ }^{77}$ Art 5(3) DSU.
} 
seldom used - arbitration has only been used once to date. ${ }^{78}$ Even in that case, arbitration was not used as an alternative to Panel proceedings, but instead to support implementation of a Panel decision. ${ }^{79}$ This shows that in actuality a legalistic litigation model is preferred by developing countries as they have proven willing to bear the increased costs of Panel and Appellate Body proceedings. Although exact reasons for this are not known, this might be explained in part by the greater certainty of WTO litigation.

In addition, a more effective way developing countries have used the dispute settlement system is as third parties in consultations and Panel proceedings. The popularity of this approach can be seen from the fact that 'developing countries account for $52 \%$ of all third parties in the WTO compared with only $36 \%$ of complainants. ${ }^{80}$ Members with 'substantial interest' are able to take part in proceedings as third parties. ${ }^{81}$ They are not simply observing but 'can deliver written and oral testimony during the first round of litigation and therefore will receive the first submissions of the complainant(s) and the defendant' ${ }^{82}$ In this way, members are engaged with the process, able to understand the workings of the legal framework and to express their trade interests without bearing the large scale costs. Moreover, acting as a third party overcomes the lack of transparency in the WTO dispute settlement system, which acts as a hurdle to developing countries accessing the system. Participation in proceedings as a third party is a good method in which to gain knowledge and experience in otherwise closed dispute settlement proceedings. A frequent user of this approach has been China, who has been party to nearly all its disputes since joining the WTO in $2003 .{ }^{83}$ This offensive approach by China has prepared it against future WTO proceedings against it. ${ }^{84}$ This creates a different narrative to the one usually recited of developing countries' apathetic approach to the WTO dispute settlement system.

Yet, participation in this way is not without its problems. Firstly, third party participation can be seen as inferior to proceedings as a complainant or defendant, as ' $[\mathrm{t}] \mathrm{hird}$ party participation can gain insight, but interests are not protected unless they enter into direct

\footnotetext{
78 World Trade Organization, 'Dispute Settlement without recourse to Panels and the Appellate Body' <https://www.wto.org/english/tratop_e/dispu_e/disp_settlement_cbt_e/c8s2p1_e.htm> accessed 12 August 2015. ${ }^{79}$ ibid.

${ }^{80}$ Marc L Busch and Eric Reinhardt, 'Three's A Crowd - Third Parties and WTO Dispute Settlement.' (2006) 58(3) World Politics 446, 461.

81 ibid 453.

82 ibid.

${ }^{83}$ Han Liyu and Henry Gao, 'China's Experience in Utilizing the WTO Dispute Settlement Mechanism' in Shaffer and Melendiz-Ortiz (n 3) 140.

84 ibid 147.
} 


\section{Member Participation in the WTO Dispute Settlement Process: \\ Can Developing Countries Afford Not to Participate?}

consultations. ${ }^{85}$ Participation as third parties also encourages free riding, an occurrence from which the WTO dispute settlement system already suffers. ${ }^{86}$ A country 'piggybacking' on another member's filing creates a level of uncertainty as to the extent to which they will benefit from another member's litigation; ${ }^{87}$ 'small countries then become dependent on circumstance'. ${ }^{88}$ This inconsistency means that developing countries are not able to consolidate their future bargaining positions. What is more, the data shows that the pattern of third party participations follows the patterns of initiation of Panel proceedings, as "[s]ome of the most frequent third parties ... have been Canada, India, Australia, Mexico, Brazil, Korea, Norway, Chile, and Switzerland. ${ }^{89}$ Third party participation is therefore 'skewed toward the largest trading states' ${ }^{90}$ Once again, this shows that the problem of low participation in the dispute settlement system lies earlier at the investigation stage.

A better method of participation by third parties may therefore be developing countries initiating joint proceedings. There have been several cases where 'developed members together with developing members have effectively launched joint proceedings'. ${ }^{91}$ In EC-Sugar, ${ }^{92}$ Thailand launched proceedings alongside Australia and Brazil against the EU. ${ }^{93}$ By doing so, Thailand avoided bearing the full cost of filing the complaint, splitting the cost of investigations with the other members. As investigating and collecting evidence can be the most technically daunting and costly part of the dispute settlement process, joint proceedings worked well to offset these costs, making the dispute settlement system more accessible.

However, developing countries face certain economic and political considerations that add to the costs of initiating Panel proceedings. An important consideration for developing countries initiating WTO dispute settlement proceedings is the possible repercussions of litigation on their relationship with trade partners. Developing countries may fear that the cost of tainting long-term trade relations with key players is much higher than the uncertain gains of market access. Maintaining positive trading relations is a particular desire for smaller developing countries that may be reliant on certain trading partners and lack alternative exporting markets if relationships sour. Other wider, political reasons besides trade may also

\footnotetext{
85 Shahin (n 45) 286.

${ }^{86}$ Bown (n 15) 290.

${ }^{87}$ Nordström and Shaffer (n 18) 591.

88 ibid.

${ }^{89}$ Busch and Reinhardt (n 80) 461.

90 ibid.

91 Abbott (n 24) 5.

92 European Communities - Export Subsidies on Sugar WT/DS283/P/R.

93 Abbott (n 24) 5.
} 
make developing countries hesitant to initiate proceedings. Historical allegiances, for example, could mean that countries would prefer to maintain positive relationships with other WTO members, making them hesitant to initiate or take part in litigation. Shahin argues that Egypt's participation in the WTO dispute settlement system reflects this, as it can be seen to shy away from voicing legitimate complaints. ${ }^{94}$

Furthermore, developing countries can have a fear of retaliation. Retaliation by respondents for initiating litigation within the WTO dispute settlement system could take many forms. To begin with developing countries may fear a reciprocation of WTO proceedings against them. There is some evidence to support this concern: 'Reinhardt found that a complainant increases the probability of a subsequent case being filed against the complainant by up to 55 times' ${ }^{95}$ Hence, in order to initiate proceedings, countries must be confident that their own trade practices do not violate trade law. Brink notes that South Africa has been a hesitant initiator of Panel proceeding as they fear scrutiny reflecting back onto them. ${ }^{96}$ In this way, budgeting for WTO litigation may also require countries to factor in their ability to respond to future complaints against them. In this way the dispute settlement system can be seen as a 'double edged sword'. Over the years, China has found itself to be a target of developed countries since joining the WTO in $2001,{ }^{97}$ being a respondent in 33 cases. ${ }^{98}$ Therefore, when active participation in the WTO dispute settlement system has the potential to create enemies, it is sensible for some countries to want to avoid the limelight of litigation.

In addition, developing countries may fear retaliation beyond the WTO. By initiating WTO proceedings against developed countries, developing countries risk losing prior privileges, aid and investment on which they have become reliant. This poses a particular concern for those LDCs who are the greatest receivers of aid. Factoring this into the dispute settlement proceedings shows a skewed balance of power between developed and developing countries going into the process. A resistance from developing countries may therefore be a case of not wanting to 'bite the hand that feeds it'. As the WTO does not contain any overt code of conduct against such practices and has few safeguards to protect countries from such behaviour, there is a lacuna in the law. The WTO does acknowledge these fears in part in its 'special and differential provisions' for developing countries discussed above, but it does not

\footnotetext{
94 Shahin (n 45) 290.

95 Guzman and Simmons (n 36) 570.

${ }^{96}$ Brink (n 19) 262.

${ }^{97}$ Liyu and Gao (n 83) 153.

98 World Trade Organization, 'China and the WTO'

<https://www.wto.org/english/thewto_e/countries_e/china_e.htm> accessed 21 August 2015.
} 


\section{Member Participation in the WTO Dispute Settlement Process: \\ Can Developing Countries Afford Not to Participate?}

go far enough in actively implementing safeguards for developing countries. In this way a stricter code of conduct forced upon developed members may go some way to extinguishing these fears.

However, the strength of the argument that fear of retaliation is a substantial factor in developing countries' lack of participation is largely diminished by reality. Guzman and Simmons in their 2005 paper ${ }^{99}$ looked into this behaviour, which they called 'power plays' ${ }^{100}$ Their analysis of WTO data found that the hypothesis that poorer countries refrain from filing complaints against richer countries due to fear of retaliation did not have any evidential support. ${ }^{101}$ More ostensible evidence against the argument is in the pattern of WTO cases themselves. In 1995, Singapore initiated a Panel compliant against its closest neighbour Malaysia, 'despite its then dependence on Malaysia for basic essentials like food and water'. ${ }^{102}$ Additionally, the only LDC-initiated case in the WTO has been of Bangladesh's anti-dumping allegations against its neighbouring country and key trade partner India. The argument is therefore counter-intuitive in nature as a fear of retaliation from trading partners would make any WTO disputes unlikely. On the contrary, '[a] mutually high degree of trade dependence is likely to contribute to the formation of Panels, as we expected on the basis of the desire to establish clear rules that reduce transaction costs'. ${ }^{103}$ Nonetheless to dismiss the argument altogether would be remiss as the weight given to this factor is dependent on individual cases and the will of developing country governments.

These fears of diplomatic break downs may therefore still be a reason why many developing countries prefer to settle WTO disputes at the consultation stage. The fact that a large amount of disputes are settled before litigation shows that developing country engagement with the WTO dispute settlement system may not be as bleak as suggested. Consultation as a form of participation in the WTO dispute settlement system generates a positive picture as to the strength of the dispute settlement framework. Settlement at the consultation stage avoids lengthy and costly litigation. The all-or-nothing character of litigation is not always necessary ${ }^{104}$ where 'the subject matter of dispute permits greater flexibility (for example, tariff rates), the parties can more easily structure appropriate transfer payments

\footnotetext{
${ }^{99}$ Guzman and Simmons (n 36).

100 ibid.

101 ibid 571.

${ }^{102}$ Michael Ewing-Chow, Alex WS Goh and Akshay Kolse Patil, 'Are Asian WTO Members Using the WTO DSU “Effectively”?’ (2013) 16 (3) J Intl Econ L 669, 688.

103 Andrew Guzman and Beth A Simmons, 'To Settle or EmPanel? An Empirical Analysis of Litigation and Settlement at the World Trade Organization' (2002) 31(1) JLS 205, 225.

104 ibid 205.
} 
through adjustments to the disputed variable'. ${ }^{105}$ Consultation is more likely to create a winwin situation that preserves the political sensitivity of trade relations.

Furthermore, in developing countries where there is a culture of non-litigation, such as Thailand and China, the consultation stage provides an amicable setting to resolve disputes. ${ }^{106}$ Consultations give members 60 days in which to reach a 'mutually satisfactory solution'. ${ }^{107}$ Within this is also the provision of Article 4(10) DSU that 'during consultations Members should give special attention to the particular problems and interests of developing country Members'. ${ }^{108}$ Although this provision 'is more declaratory than operative', ${ }^{109}$ it does follow the general principle within the dispute settlement system of preferential treatment to developing and LDC members.

Busch and Reinhardt argue that the success of the consultations and the WTO dispute settlement system in general is because members are bargaining in the shadow of the law. Even though the dispute settlement system has been criticised for a lack of enforceability of Panel and Appellate Body decisions, this does not hinder the process. ${ }^{110}$ Instead members bargain in the shadow of the law:

A panel ruling carries weight to the extent that it delivers a timely and coherent normative statement on the matter. Even without a credible threat by a complainant to seek authorization to retaliate, a definitive legal opinion from the institution may empower groups in the defendant state who oppose the measure. ${ }^{111}$

Thus, developing countries have stronger bargaining positions within the dispute settlement system than they would if they attempted to bargain outside of the WTO. Busch and Reinhardt therefore argue that 'the central problem for developing countries is that they are missing out on early settlement, not that they boast a worse record in winning pro-plaintiff rulings'. ${ }^{112}$ Consequently, their solution is that developing countries should receive more assistance before litigation commences. ${ }^{113}$ Although this argument coincides with the idea that the model of litigation is not the essence of the issue, this paper goes further to suggest that the problem lies

\footnotetext{
105 ibid.

${ }^{106}$ Liyu and Gao (n 83) 165.

${ }^{107}$ Lekgowe (n 51) 5.

108 ibid 8.

109 ibid.

${ }^{110}$ Marc L Busch and Eric Reinhardt, 'Bargaining in the Shadow of the Law: Early Settlement in GATT/WTO Disputes' (2000) 24(1) Fordham International Law Journal 158.

111 ibid 165.

112 Marc L Busch and Eric Reinhardt, 'Developing countries and GATT/WTO dispute settlement' (2003) 37 (4) J World Trade 719, 722 .

113 ibid 721.
} 


\section{Member Participation in the WTO Dispute Settlement Process: \\ Can Developing Countries Afford Not to Participate?}

even before the consultation stage. The problem is one of capacity issues in investigating and monitoring potential trade violations.

\section{Issues of capacity}

The section above shows that while the inherent cost of the WTO dispute settlement system is a determining factor for developing country participation, it is not the core of the problem. The fact that the WTO system contains numerous ways in which developing countries can reduce the cost of participation establishes that the problem lies more with developing countries' capacity to initiate proceedings. Browne takes us to the heart of the matter, that 'there seems to be little in the WTO system per se that needs correcting in this context. It is rather problems of internal governance and organization in many capitals that may be responsible for the relative absence of many members from the WTO dispute scene'. ${ }^{114}$ Linked to participation in the dispute settlement system is the requirement of members to have the internal capacity to bring trade violations to the WTO. Although these capacity issues are individual to countries, by comparing the internal capacity of active developing countries with the capacity of those developing countries that have low participation rates, areas for reform can be identified.

The internal capacity needed within members in order to successfully initiate WTO dispute settlement proceedings can be seen as a tripartite connection between trade experts, government and the private sector. ${ }^{115}$ Larger developing countries such as Brazil, Argentina and China have in recent years built on these three pillars to create strong internal capacity. Developing countries that fail to participate fully in the WTO dispute settlement system are likely to do so because one or all of these components are weak within the country. What is meant by full participation is the ability of member governments to identify trade violations and undertake an accurate cost-benefit analysis to bring viable cases to the WTO.

In order to successfully bring claims to the WTO dispute settlement system, developing countries must begin with building internal trade expertise. The primary way to gain internal trade expertise is through maintaining home-grown talent. To begin with, incorporating trade and trade-related issues into the education system will create a pool of trade experts from which the country will benefit. ${ }^{116}$ For example, the introduction of higher education courses in trade at universities will encourage a new generation of students and lawyers interested in specialising within this area. ${ }^{117}$ Brazil has done this by creating a ' $[\mathrm{s}]$ mall Brazilian epistemic

\footnotetext{
114 Abbot (n 25) 1.

115 Gregory Shaffer, Michelle Ratton Sanchez Badin, and Barbara Rosenburg, 'Winning at The WTO: The Development of a Trade Policy Community Within Brazil' in Shaffer and Melendiz-Ortiz (n 3) 26.

116 ibid.

117 ibid 32.
} 
community specialising in trade matters', ${ }^{118}$ where scholars, practitioners and trade associates gather in order to establish progress and debate. ${ }^{119}$ Alongside education, developing countries need to do more to retain talent and expertise within the country. It is of little surprise that trade lawyers and experts in WTO law mostly reside within the US and EU where there are greater educational and job opportunities. ${ }^{120}$ Therefore a common problem that developing countries face is ' $[\mathrm{t}]$ he loss of the few knowledgeable people'. ${ }^{121}$ Accordingly, in order to maintain expertise within the country, governments need to ensure that education in trade issues is followed with practical job opportunities in order to avoid expertise leaving the country.

Linked to this is the second pillar to building strong internal capacity, which is developing governments having a clear and sufficiently resourced trade agenda. As discussed in the first section of this paper, engagement with the WTO dispute settlement system is paramount for governments to effectively pursue their trade interests. One way to ensure that there is a focus on trade policy in developing countries is by creating specialised trade departments in government. ${ }^{122}$ These departments need to be funded centrally and have the authority to pursue trade policy. The problem for developing countries and LDCs is their greater limitation on resources and money. Small government budgets that must be distributed across all social welfare needs (eg healthcare, education and infrastructure) mean that trade is not necessarily a priority for government spending. Moreover, in small countries where their volume of world trade is low, the opportunity cost of spending money on trade may not be seen to be worth the minimal returns in market access. Placing long-term funding into trade departments when WTO cases remain few and far between could be considered a waste. Therefore, what is essential is the will of governments to recognise the benefits of investment in trade issues, in terms of its positive effect on specific economic outcomes, trade terms and future bargaining positions.

Finally, vital to the tripartite model of internal trade capacity is the engagement of the private sector. As many of the violations of trade originate in the private sector, it is essential that the private sector engages with central government departments in order to identify and progress viable WTO cases. A developing country's exporters are best placed to be able to monitor and identify when trade violations take place. Their direct financial interest means that they will be motivated to monitor markets. Their understanding of international markets and

\footnotetext{
118 ibid 57.

119 ibid.

120 ibid 58.

${ }^{121}$ Brink (n 19) 267.

122 Shaffer, Badin, and Rosenburg (n 115) 43.
} 


\section{Member Participation in the WTO Dispute Settlement Process: Can Developing Countries Afford Not to Participate?}

industry competition is therefore essential for generating strong cases of violations to bring to the WTO disputes settlement system. In this way it is essential that there is an ease of engagement between the private sector and government to facilitate the frequent sharing of information. Thus, when all three communities of the tripartite system work effectively together accurate cost-benefit analysis can be conducted by developing countries, resulting in worthwhile cases being brought to the WTO dispute settlement system.

With the intention of solving some of the capacity issues above, the ACWL provide developing countries with tools to build their legal capacity in trade. As discussed earlier, the ACWL implements a two-tier approach supporting developing countries and LDCs in WTO proceedings. Whilst the first deals with reducing fees, the second tier deals with building capacity, recognising that '[a] WTO member can seize these opportunities only if it understands its rights and obligations as a WTO member and if it understands how the WTO conducts negotiations, takes decisions and settles disputes'. ${ }^{123}$ The ACWL offers developing countries and LDCs training in WTO law through annual courses, seminars and training sessions. ${ }^{124}$ The ACWL works directly with government trade lawyers in order to build expertise within developing countries. Its Secondment Programme for Trade Lawyers offers a nine month paid internship in which those lawyers are trained by ACWL lawyers. It is hoped that those government lawyers will be able to bring expertise back to their countries and incorporate their knowledge into the government infrastructure. Likewise, ACWL seminars and courses provide information on substantive and procedural elements of the WTO, keeping countries up to date on contemporary trade issues. ${ }^{125}$ The WTO itself also offers developing countries additional resources and training on dispute settlement. Its own internship programme, ${ }^{126}$ one-week Dispute Settlement Course, ${ }^{127}$ and teach-yourself videos ${ }^{128}$ found on its website are easily accessible to all members requiring information on WTO law. In doing so, the ACWL and WTO mitigate basic capacity issues found in developing countries, although other challenges remain.

Some of the primary barriers for developing countries and LDCs in bringing proceedings into the WTO are cultural differences. In particular for non-western countries,

\footnotetext{
${ }^{123}$ The Advisory Centre on WTO Law, 'The ACWL's Mission' < http://www.acwl.ch/e/about/about_us.html $>$ accessed 19 August 2015.

${ }^{124}$ The Advisory Centre on WTO Law, 'Training' $<$ http://www.acwl.ch/e/training/training.html $>$ accessed 19 August 2015.

125 ibid.

${ }^{126}$ World Trade Organization (n 4).

${ }^{127}$ Browne (n 10) 32.

128 ibid.
} 
language barriers exist between national languages and the WTO dispute settlement system, making it more difficult for internal experts to interpret legal documents and respond to complaints. Whereas most WTO cases are published in English, French, and Spanish, countries not well-versed in these languages - typically Southeast Asian and African members - are disadvantaged in their ability to quickly and accurately understand the WTO jurisprudence. ${ }^{129}$ In addition the WTO judicial framework is less familiar to countries that lack a common law experience. ${ }^{130}$ These developing countries can thus benefit from the additional training and support offered by the ACWL and WTO so as to engage effectively with the system.

Yet, while the ACWL and WTO help developing countries build basic capacity, they are limited in their ability to resolve deep-seated gaps. The nature of WTO and ACWL internships and courses is that they are on the whole conducted 'on the premises'. ${ }^{131}$ This requires developing governments to fund their trade lawyers' travel and stay in Geneva, yet many developing countries cannot afford to do so due to the costs and existing problems of short-staffed departments. The availability of online resources and training materials has gone some way in tackling this weakness of WTO and ACWL training, but more can be done on a regional level to make training more accessible to developing countries. Mosoti highlights how 'African countries have already come up with modalities on how to optimally utilise their scarce human resource potential', ${ }^{132}$ by having the African member representatives in Geneva brief each other on focal points for Doha negotiations. ${ }^{133}$ Following this initiative, developing countries could create a similar scheme for WTO dispute settlement. Regional conferences on the dispute settlement system where experts can share their knowledge would expand awareness in low participating regions. Taking this approach further, Mosoti suggests establishing regional advisory centres on WTO law as an effective solution to create long-term capacity at a low cost. ${ }^{134}$ Although such a reform would be effective in strengthening the two components of trade expertise and government capacity within the tripartite model, building engagement of the private sector with government trade departments is best achieved internally by developing countries' governments.

\footnotetext{
${ }^{129}$ Liyu and Gao (n 83) 147.

130 ibid 167.

${ }^{131}$ ACWL (n 124).

132 Mosoti (n 11) 452.

133 ibid.

134 ibid 453.
} 


\section{Member Participation in the WTO Dispute Settlement Process: Can Developing Countries Afford Not to Participate?}

\section{E. DRIVING INTERNAL CAPACITY IN DEVELOPING COUNTRIES}

The sections above have shown that the core of the problem of developing countries' participation lies with identifying WTO violations and the ability of government to accurately assess the viability of bringing these cases into the dispute settlement system. From the evidence, this can be narrowed further into an internal capacity problem within developing countries regarding a lack of convergence between the private sector and government. In this way, as the problem is mostly internal within countries, much of the reform must also be initiated internally.

In their 2010 study, Bown and McCulloch found that the 'observability' of violations is a key factor in the type of measures brought by both developing and developed countries to the WTO. ${ }^{135}$ They found that developing countries that initiated WTO proceedings as complainants did so mostly for cases of antidumping and countervailing, as these violations are the most obvious for members to identify. ${ }^{136}$ In contrast, 'the EC and the US dominate disputes initiated over low observability measures, and such complaints are much less frequently initiated by developing countries'. ${ }^{137}$ It is strongly suggested by the evidence that developing countries lack the capacity to identify less obvious trade violations. This hinders the frequency of developing countries' potential engagement with the dispute settlement system.

Unlike what has often been the case for developing countries, strengthening observability of trade violations must come from active reform by governments and cannot be left to circumstance. It can be seen that, in Argentina for instance, 'the requirement to defend against cases triggered a governmental capacity building process of human resources devoted to WTO' ${ }^{138}$ Similarly, Brazil's participation in early WTO cases had a catalysing effect on the government's commitment to building internal capacity, stimulating competition for traderelated expertise within the country. ${ }^{139}$ Therefore, these developing countries can be seen to have built capacity not through active mandate but a result of circumstance. Although participation as respondents in the WTO dispute settlement system had unintended positive affects for these countries, the sustainability of trade capacity is reliant on government's proactive reforms. These two case studies do however show how external sources, such as increased media coverage on WTO disputes, can also help raise awareness and debate on trade

\footnotetext{
135 Bown and McCulloch (n 65) 45.

136 ibid 45.

137 ibid 47.

138 Gabilondo (n 26) 7.

139 Shaffer, Badin, and Rosenburg (n 115) 56.
} 
policy. ${ }^{140}$ While recognising that capacity building is partly a natural process, this does not mean that the only incentive to build trade capacity must be from necessity. A more considered long-term plan would serve developing countries better.

It is argued here that as the private sector is best placed to monitor and investigate WTO violations, engagement between the private sector and central government is vital. The problem of low developing country participation arises because this relationship between the private sector and government is weak. Private industry is the initial driving force for trade violations reaching the dispute settlement stage, as it is that pressure and information that gives governments the will to pursue viable cases. Thus, if the private sector is unaware that its rights are being violated in the first place, then it will be unable to escalate concerns to its government. Additionally, if the private sector does not have a clear platform through which to access the government, then again there are obstacles to bringing violations to the WTO. In this way a lack of knowledge in the private sector and lack of access to government would need to be addressed.

Firstly, in circumstances where the private sector is active in investigating trade violations, Bown and Hoekman suggest that the "public-private model requires a public sector counterpart that has the mandate and competence - both legally and administratively - to pursue the interests of the private sector' ${ }^{141}$ As we have seen from the present low participation rates in developing countries, 'leaving its supply to market forces alone will likely lead to under-provision for standard economic reasons'. ${ }^{142}$ It is therefore essential that governments are able to respond to private sector calls for progression of cases to the WTO dispute settlement system. If governments do not have the resources or expertise, they will miss opportunities to bring legitimate concerns to trade partners. A lack of action by governments on repeated occasions can consequently cause antipathy in the private sector. Developing countries must therefore invest in having an accessible way in which the private sector can escalate concerns and receive efficient responses. Some ways in which this can be achieved are through specialised central government departments, an Ombudsman, ${ }^{143}$ or research committees.

Secondly, where the issues are a lack of will in government and a lack of knowledge of rights in the private sector, the formation of trade associations can help. ${ }^{144}$ As seen within larger

\footnotetext{
140 ibid 35.

${ }^{141}$ Bown and Hoekman (n 13) 872.

142 ibid 873.

${ }^{143}$ Bown (n 15) 17.

144 Shaffer, Badin, and Rosenburg (n 115) 79.
} 


\section{Member Participation in the WTO Dispute Settlement Process: Can Developing Countries Afford Not to Participate?}

developing countries, the establishment of strong trade associations has increased the monitoring of trade and reduced the overall cost of monitoring for individual companies by encouraging a sharing of industry trends and resources. ${ }^{145}$ More importantly, the result of trade associations is a greater political voice with which industries can approach government. It is not surprising that those sectors with powerful lobbies (such as clothing and agriculture) are most successful in approaching government with their concerns. ${ }^{146}$ Both the private sector and government benefit from industries having a strong political voice. The private sector creates accountability within government, providing a check on trade policy to ensure that governments are not idle. In addition to this government benefits from the fact that the private sector takes on the costs of investigating and evidence finding for potential WTO cases. It is also argued that the private sector is best placed to absorb these costs as loss of market access hurts their financial interests.

Superficially there is reason to think that an independent prosecutor in the WTO may be a positive reform. However, looking into the viability of the approach shows that it is fraught with obstacles. The suggestion that the WTO dispute settlement system should have an independent prosecutor is based on the idea that this prosecutor would be better able to undertake the investigation and fact-finding role that developing countries are weak in performing. This would mean that developing countries with little internal capacity to support investigations would be able to bring cases to the WTO dispute settlement system. Yet looking broadly at other international organisations that have used this approach shows that there are many problems in having an independent prosecutor. A clear example is the International Criminal Court (ICC), which is headed by an independent prosecutor from member states on a rotating basis. The ICC in recent years can be seen to be struggling with the lack of resources and political will to manage its growing caseloads. Moreover, the role of prosecutor has become highly political, hindering the prosecutor's ability to bring the accused to court. For this reason the WTO is better off remaining a self-representative system that is member-driven and adheres to a rule of law.

Nevertheless, this does not mean that developing countries must solely carry the cost of reform. Like the ACWL, NGOs could provide developing countries with the ability to build internal capacity. Bown and Hoekman show that large NGOs with a local presence are able to identify whether the local business interests in market access are worth taking to the WTO

\footnotetext{
145 ibid.

${ }^{146}$ Horn, Mavroidis, and Nordström (n 16) 4.
} 
dispute settlement system. 'Thus, local NGO offices or entities could help mobilize the publicprivate partnership required to use the DSU most effectively by helping to identify cases that could be brought to domestic government officials with evidence that they are worthy of pursuit at the WTO'. ${ }^{147}$ In this way, NGOs can help raise the private sector's awareness of their rights under WTO law and assist in the monitoring of trade violations. NGOs (such as International Lawyers and Economists Against Poverty) that provide trade-related technical assistance to developing countries would be able to help governments in their cost-benefit analysis. ${ }^{148}$ Although developing countries are generally hesitant regarding NGO participation in the WTO, ${ }^{149}$ opening themselves up to such provisions could help them fill the current gap between private sector and central government engagement.

\section{F. CONCLUSION}

This paper aimed to undertake a comprehensive discussion of the reasons for the low level of developing country participation in the WTO dispute settlement system. It is argued here that the approach that developing countries should take to the question of participation is ultimately a cost-benefit analysis. The first section of the paper shows that in considering the benefits to participation, developing countries are aware of the economic stakes, but largely underestimate the wider strategic importance of participation. Moreover, in identifying the reasons why developing countries fail to participate, although the cost issues of the dispute settlement system are frequently acknowledged as the primary obstacle for developing countries, these costs are overstated. The trends in actual participation show that developing countries can use the system in shrewd ways that reduce the inherent costs of the WTO litigation procedure. What is most important is that developing countries must be more willing to capitalise on the support available within the WTO and outside of it in order to offset cost and capacity issues. Therefore the question posed in this paper is not of whether developing countries can afford to participate, but whether they have the capacity to do so. In answer to this latter question, it is found that smaller developing countries do not. Developing countries and LDCs are able to litigate within the WTO dispute settlement system, but at the outset lack the ability to make accurate decisions as to the viability of bringing trade violations to the WTO. As this decision is reliant on technical knowledge and legal expertise, a common weakness among small developing countries is with the engagement of the private sector with government. As this

\footnotetext{
${ }^{147}$ Bown and Hoekman (n 13) 883.

148 ibid 876.

149 ibid 870 .
} 
capacity issue is distinctly internal, external organisation such as the WTO and ACWL are limited in the support they can provide. More so, the WTO cannot be expected to do much more than it already does. Instead, increased governmental awareness of trade rights in the private sector would provide a more organic solution. 